\title{
Reconceptualizing Expressive Arts Education in Portugal through a Biographical Narrative Approach
}

\author{
André Freitas ${ }^{1, *(D)}$, Fátima Pereira ${ }^{1}(\mathbb{D})$ and Paulo Nogueira ${ }^{1,2}(\mathbb{D}$ \\ 1 Centre for Research and Intervention in Education, Faculty of Psychology and Education Sciences, \\ University of Porto, Rua Alfredo Allen, 4200-135 Porto, Portugal; fpereira@fpce.up.pt (F.P.); \\ pnogueira@fpce.up.pt (P.N.) \\ 2 Research Institute of Art, Design and Society, Faculty of Fine Arts, University of Porto, \\ Av. de Rodrigues de Freitas, 4049-021 Porto, Portugal \\ * Correspondence: andrefreitas@fpce.up.pt
}

Received: 2 November 2020; Accepted: 2 December 2020; Published: 18 December 2020

\begin{abstract}
In light of ongoing controversies concerning expressive arts education in Portuguese primary schools, the life history of one primary-school teacher who lives and works in the city of Porto (Portugal) is the starting point for problematizing this issue from the perspective of lived experiences. Data collection comprises oral reports, visual materials, and emotional accounts. Feelings were shared in a relational environment framed by ethical commitments. Through these processes, it was possible to create a narrative within the framework of a biographical narrative research approach. The main purpose was to highlight the voice of one primary-school teacher whose life history is blended with the foundations and practices of artistic expression in basic education-such as language, communication, knowledge, and lived experiences-making it an important starting point for reconceptualizing expressive arts education. The results showed that this reconceptualization can be achieved through three dimensions: seducing people, mediating places, and governing senses.
\end{abstract}

Keywords: biographical narrative methodology; expressive arts education; artistic expressivity experience

\section{Introduction}

Expressive arts education is a component of basic education, which, when include in organized curricular knowledge [1], enhances the capacity for personal expression [2]. A school as a social context that promotes experiences and educational goals for personal development [3] is the "setting" for experiences of artistic expressivity. To understand the particularities of this subject, it is important to be aware of how this education process is carried out in national [4,5] and international $[6,7]$ contexts. There is evidence of insufficient teacher education related to planning, development, and assessment [1] for expressive arts education. Likewise, there is an absence of adequate resources in schools, which are needed for the development of children [8] learning this subject. Expressive arts education is often merely viewed as a chance for "relaxation" [9] or as playing a "decorative" role in schooling [10], while the acquisition of other knowledge is often considered more relevant [11], justifying instrumentalization of the arts. This also highlights the need to give visibility to the stories and lived experiences of those who work in arts education by sharing their perspectives, how they live, what they have done, and what knowledge these experiences generates [12,13].

Being aware of Bruner's and Dewey's $[13,14]$ idea of people as creatures who change through time, such a change must also happen in education. We are also aware of the successive attempts towards art education reconceptualization in recent decades [1], which have had different emphases [15] but all of which promoted positive changes and advances in the field [16]. We are also aware that these efforts have not yet translated into changes in our education, in our schools, or in our lives [8]. 
It is important to continue this debate even today. Our scientific and political positions are that the reconceptualization of art education can occur through a biographical narrative approach, increasing the awareness of people's senses of place and time and their interactions. Thus, the main purpose of this paper is to highlight the voice of one primary-school teacher as a means of reconceptualizing expressive arts education while being aware that our idea of reconceptualization is focused on an idiosyncratic method and that we are not interested in promoting a prescription for education or for general best practices for schools. The biographical narrative method [17] as a research methodology allows for the possibility of reinventing and reconceptualizing expressive arts education in the basic education context. Thus, the goal of this research is to problematize the meanings that are attributed in the life history of a primary-school teacher and her experiences in expressive arts education and to understand the tensions that occur in her profession. Through her life story (a life story is centered on the unique character of the individual [18,19], which according to Goodson [20] is a narrative of actions), it is possible to create her narrative [21]. Thus, this work problematizes some of the dimensions that constitute primary-school teacher Rosa do Mar's (fictitious name) life history (a life history contextualizes and politicizes the discourse and triangulates it with other documents and dimensions [18,19], which according to Goodson [20] is a genealogy of the context), focusing on her education, her curricular and pedagogical work, and finally the artistic expressivity of her body as a structured argument (that is transferable to all work) of research, through which Rosa do Mar remembers, is surprised, and dreams.

Biographical narrative research $[17,18]$, the method framing this research, generally relates to larger-scale research projects with more "authors" and more research "scenarios". This work focuses on problematization of one of the narratives constituting this project-that of Rosa do Mar from the School of Stories (fictitious name). The School of Stories is located in the Portuguese Northern region, with agricultural and industrial roots and with a textile art tradition, which is home to 23,000 inhabitants. The art that traditionally energized this community is less prominent nowadays, with the community resembling more of an urban center with a focus on local commerce and services, according to the social and cultural contextualization of the school's educational project. Based on a school external evaluation report (2014-2015), the percentage of pupils in the school without economic aid is above average in comparison with other similar educational institutions throughout the country.

The School of Stories' educational project presents as its guiding principles and values the defense and promotion of the quality of learning, valuing and promoting a taste for culture, science, and the arts. The general objectives and guidelines are to promote an integral education approach for children, creating a climate of knowledge and fostering a humanistic, artistic, scientific, supportive, and technical culture which will enable children to define their interests and motivations. Regarding human resources, there are 15 teachers (93.9\% of whom have been teaching for 10 years or more). Additionally, there are 13 people responsible for management and technical and operational support. The number of children enrolled as pupils in the first cycle of basic education was 315, according to data from 2013-2014. The school's building was built in a new residential area and was subject to refurbishment work financed by the municipality in 2005. The facilities included eight classrooms; a library; a cafeteria; a canteen; and a hygienic, technical, and administrative support area. In relation to exterior areas, the existence of an atrium, a park, a playground, and a vegetable garden is highlighted.

Biographical narrative research is an area of study that started in the 1990s and, therefore, is still emergent. From its theoretical referents to its implementation, this methodological approach allows for data collection (sharing of information) and its analysis. This paper begins with the presentation of Rosa do Mar's biographical narrative. After the biographical narrative of Rosa do Mar, the theoretical and methodological problematization of the method are presented within the framework of a hermeneutic-relational biographical narrative research.

Considering this biographical work privileging the voice of primary-school teacher Rosa do Mar through narrative processes, the theoretical debate begins in an open and composed dialogue with visual and oral reports translated into visual and textual forms [19]. Expressive arts education as 
experienced by Rosa do Mar, the curricular and pedagogical work between expressive arts education and the artistic expressiveness of Rosa do Mar, and the personal expression and artistic expressiveness of the body of Rosa do Mar stand out as dimensions of problematization of this work. The research concludes with considerations on the meanings arising from this biographical narrative in regard to the three analysis dimensions, exploring both the teacher experience in expressive arts education and the tensions emerging from her performance.

\section{Biographical Narrative of Rosa do Mar, Primary-School Teacher: From Early until Arriving to Porto/Her Arrival, Stay, and Departure}

Rosa do Mar (irreverent and provocative) lived in a convent of nuns when she was young. Her daily routine was very rigorous - in time, space, and interactions—so she would turn the study room (whenever she could) into a ball. From the top floor, through a window, she watched the nuns. Rosa do Mar and her friends sang songs "with plates, pots, pans, and spoons" and danced in ways "that could be heard in church"; these moments were perceived by her and her peers as disturbances that made life joyful. She associated herself with what she calls "movements of the opposition" (this refers to the revolution that took place in Portugal on 25 April 1974. Known as the Carnation Revolution, it ended the longest dictatorship in Europe: the Estado Novo. This topic will be further problematized in the next pages). In 1974, she finished her compulsory studies and enrolled in a course that would allow her to become a teacher, a dream she was nurturing at the time despite mishaps, accidents, and casualties that challenged her will. She was a good student. Hoping to get permission from her father, Rosa do Mar left the convent. This was a difficult step to take for Rosa do Mar. Her father always preferred her daughter to stay at home. Unhappy with the possibilities of life that laid ahead-bound to assisting the family business in an environment that was at times hostile and in which dialogue was not common-and between expressions of power, anger, and happiness, Rosa do Mar would become one of the few ninety candidates accepted to attend the Primary Instruction School. It was her opportunity to be different and to do differently, consistent with her "ideas of flying". Rosa do Mar did not just want this opportunity, she needed it. It would be a significant change in her life. Of the many friendships she experienced during her initial teacher education course in Primary Instruction School, one of her teachers, Professor Chico Beja (Francisco Beja, who died in the recent year 2018), was an avant-garde teacher who taught her to live music, to live theatre, and to live life, interpreting it and giving it meaning.

In 1979, Rosa do Mar finished the course and started travelling to the South Center area of Portugal, where she was responsible for her first class—teaching adults. Younger than her students, it would be Rosa do Mar learning how to write and how to speak. From Bragança to Alentejo ("Bragança" (North) and "Alentejo" (South Center) are Portuguese regions. In the next pages, there will be references to "Odemira", "Mancelos", and "Amarante". They are also Portuguese regions.), there is $500 \mathrm{~km}$ of road and as many expressions and dialects. Her home would also become the home of other teachers who arrived due to teaching duty. Rosa do Mar was the one who demanded to be in the Jeep with the education delegate to welcome, at the train station, those who arrived with what she called the teacher's survival kit: a cooker and a mattress. With stories on the doorstep, and songs and conversations in the village cafe, sharing, laughing, and venturing at school, Rosa do Mar enjoyed the months, weeks, days, and hours under the Alentejo heat while teaching — to adults-happened only at the end of the day. Her mornings were spent reading in the shade, walking in the park, and meeting at the beach. In cut dresses, English sandals, and sockets folded in summer and big heavy boots in winter, Rosa do Mar had apparently lived without restlessness, despite encounters with several of "life's bad luck".

In view of her desire for independence, she needed to financially supplement the monthly income for her service as a teacher. In the meantime, she also got married-more to please her parents than herself-and had a son-who she carried on her back to the nineteen schools she worked at. She sewed, and it was between threads, needles, fabrics, and buttons that she allowed herself to continue to explore her taste and predisposition for artistic work, which led her to design and make costumes for the plays 
and role-plays she organized with her pupils. With interests in teaching in the classroom how to grab a pencil and, through the gesture, in manifesting herself on paper, until she taught how to sew and glue, she worked on dreams and wishes-even those that would be difficult to pronounce. Committed to providing various experiences to her students-who, in the meantime, became children in the early years of basic education - she soon found the potential of artistic expression as an atmosphere for the time and space they shared. Plastic bags became aprons, buttons were sewn, and affections were shared.

She had more home addresses than schools assigned to work at. Rosa do Mar made more friends among colleagues than travelled roads to visit family and fell in love more often than possible. Rosa do Mar lived between emotion and creation.

In an atmosphere of resistance and doubt, she would hear between her steps from the entrance of the school to the entrance of the room: "But, who is she? Now you think you're in charge here? That's what was missing. Now she's in charge." Hired by the School Libraries Network, Rosa do Mar arrived in 2009 at a school which welcomes her to this day. Seen as a strange element who thinks differently and acts differently, she started working as a librarian teacher at the school that she would succeed to transform: the School of Stories. The glances that she felt and the comments that she heard made it difficult for her to integrate. Her motivation and dedication made it possible for her to overcome these constraints. The mission and values inherent to her professional practice could continue to be what she believed in: to provide a triumphant experience of artistic expressions for children during their educational journey. She inspired people and was the inspiration for stories. She encouraged men, women, children, and families to read books, to use different painting materials, and to use computers-in the logic of active participation, where dialogue, creation, reflection, and discussion would become organizational structures for the school's pedagogical work, starting at the door that once served only as a quick passage: "It took a few months to put everything into the organization that a School of Stories requires."

Years later, the environment became a space of respect and curiosity. It was a period of renewal for Rosa do Mar which had the support of the local educational management and school coordination. Gaining the trust of others facilitated her work. Her experience at the school came to "stabilize" and to unfold more and more with other educational agents and with other structures of social organization that allowed more and more stories to exist in the-now surely-School of Stories. Rosa do Mar once heard "Keep going, you're fine. It is a good job. I want you to go on, and even if you want to, do more." This change was a boost that came to safeguard the personal investment she was making in the school. Rosa do Mar "seduced" people towards the added value of having a story-centered school. Also, she managed to replicate this experience in two other schools with which she currently collaborates. Rosa do Mar, while "agencying" the space, made it open to all who were interested in what it had to offer, forming groups of support, dissemination, and research of their work. Rosa do Mar "governed" a difficult world of definitions, meanings, and knowledge, implementing processes of monitoring and evaluation of activities in order to preserve the experiences. Rosa do Mar "blessed" us with her life, allowing the particularities that, for a decade, she sowed to flourish and find new shapes, new colors, and new meanings.

She was in her sixties when she started preparing for her departure (retirement). That happens in a school environment that values and recognizes already strengthened roots and those that are beginning to emerge. "Happy and fatigued", Rosa do Mar began to plan her next flights. From the certainty of knowing that she cannot distance herself from her commitment to what makes her happy, she began to find possibilities that did not leave her exhausted-although curiously, this was the goal of her work. Rosa do Mar wanted to fill up as much space and time as possible with a thousand pieces of information in an endless whirlwind. Her work space, which she still inhabited for a few years, had become crowded, filled with materials she collected during her life, filled with artefacts that remind her of many lived stories, filled with children who queue up at the door to get their place, and filled with many feelings that are the reflection of Rosa do Mar as a primary-school teacher. 
Rosa do Mar remembers, is surprised, and dreams about the people, she has met, knows, and will meet; the places she has crossed, crosses, and will cross; and the stories in which she certainly was, is, and will be one of the main characters.

\section{Biographical Narrative as a Research Method: From Theory to Operability}

The life story of primary-school teacher Rosa do Mar allows for the development of an original argument that enhances the problematization of expressive arts education as knowledge that integrates the professional practice of teachers from the early years of basic education. Biographical narrative research as a methodology, narrative research as a method, and narrative thinking as an approach make it possible to develop research in education that acknowledges people's lives through the promotion of a theoretical and methodological sphere that gives meaning to the understanding of their experiences [17]. The aim of this paper is to problematize the meanings attributed to the life history of a teacher in the first years of basic education about her experiences with expressive arts education, understanding the tensions felt in her profession throughout her life. Therefore, through the events narrated in this life history, we bear witness to the value of experience as a process of self-education and, mainly, as a key element in learning "how to do art education". Understanding "biographical" as the lived experiences [13] and "narrative" as the possibility to create meaning from those experiences [17], we develop our argument. Clandinin and Connelly [17] recognize biographical narrative as the best option for researching experiences with the intention to create new ways of perceiving time and space in education, people, and their interactions [13].

"If we are to understand something as intensely personal as the work of being a teacher, it is essential that we know the teacher as a person." [22] (p. 29). From this point of view, we began the journey of knowing the life experiences of Rosa do Mar through a narrative approach [17].

With the aim of valuing the voice of Rosa do Mar, problematizing it with the scientific production already developed, the method of biographical narrative research is used to contribute to the development of an area that is still growing [18,23,24]. In this line of thought, we rely on Eça's [25] approach, which refers to biographies as specific strategies that promote the production of meanings in the relationship between art and education, corresponding at the same time to the promotion of hopes, dreams, and knowledge [11]. Moreover, Freedman's work [11] states that the biographical approach as a method based on daily-living experiences is a fundamental way to understand art education and its specific conditions. The perception that a life story incorporates hopes, dreams, and knowledge allows for the assignment of meanings [24] in lived experiences. The experiences which constitute the history of life are organized from opportunities of interpretation [13].

The biographical narrative method develops from the collection of life stories [18], allowing the constitution of narratives that acknowledge the specificities of place, temporality, and sociability [26]. Amado and Ferreira [27] highlight the purpose of this type of research and how it can become operational:

A type of research that aims to capture, through a story/narrative, the interpretation that a person makes of her life journey, with the respective diversity of experiences and personal feelings that take place over time and in phases, in the most diverse circumstances or contexts and in connection with a multiplicity of subjects and systems. [27] (p. 171)

From this understanding, the accounts of Rosa do Mar's life and the sharing of various personal artefacts, such as photographs, made the construction of this narrative possible [19,21] in a work of intersubjective interpretation $[13,23]$ between the researchers and Rosa do Mar. Since research on the life and work of teachers "presumes a powerful antidote for deliberate obfuscation" [22] (p. 35)—which has been going on for too long-it allows for ideas, initiatives, and reinventions and re-conceptualizations that directly affect education to emerge [22]. This paper, then, comprises research that aims to distinguish itself by the information, valuation, and recognition of life history as a strategy for knowledge production in education [17]. 
Clandinin and Connelly's work [17] also makes it possible to explain the method of biographical narrative as epistemological and methodological organization that increases the visibility of and the possibilities for using teachers' perspectives. Since it is taken into account through an agreement between researcher and research participant that there will be room for the interpretation of meanings given to lived experiences, a set of ethical formulations emerged. Initially, we took interpretation as an approach that is interested in understanding the meanings that the participant attributes to the actions in which she engages [27] by decoding voices [28]. Hence, an understanding that assigning meanings is a work of intersubjectivity, since it is being shared, is clearly necessary to initiate an ethical debate on the problematization of the biographical narrative method.

Understanding ethics as a distinctive dimension of the human condition [12], researchers and participants are in between instability, change, and contingency [29]. Such particularities of the human relationship and, therefore, of ethics demands to acknowledge that "I implicate on the Other." [30]. Rejecting the position and discourse of one about the other, which would translate into a suppression of the other and a universal thought [30], reinforces this as a research which understands the other as constituted by their critical thinking, their being in society, and their capability. This is an emergency line of educational research which, according to Amado [27] (p. 187) "is based on an essential basis of trust between the parties involved". Thus, by respecting the other, it is possible to create a safe environment for sharing. Informed, formal, institutional, and signed consent embodies and establishes the commitment in a relationship that is constantly negotiated between researchers and participants. The research participant's transfer of time, space, and personal commitment to the research relies on the ethical attitude of the researchers [23], assuming the role of a privileged listener to the participant's experiences [18] and ensuring the existence of respect, anonymity, and confidentiality. Rosa do Mar was informed that her contributions would be the object of reflection and would be subject to the subjectivities of the narrative researchers, as the latter has autonomy in the relationship established with the theoretical framework of the research to interpret and publish the contributions.

In the encounters between Rosa do Mar and the researchers, which allowed for the sharing process that constitutes the basis of the work hereby presented, Rosa do Mar, as the privileged participant in this "encounter", emerged as an available and committed special informant with good narration skills [17]. The selection of Rosa do Mar as the participant followed a thorough search for institutions and teachers referenced by specialists of high academic merit with research work in expressive arts education in the region of North of Portugal and who were framed by educational projects that included the expressive arts education as a valued area, present in the school's action plans and activities. The first encounter with Rosa do Mar took place at the School of Stories-the school where she works. The interactions between researchers and Rosa do Mar began in November 2017 and lasted until April 2018. Subsequently, a closer and more regular relationship was restored between February 2019 and April of the same year. During this time, weekly encounters occurred, in which histories and stories were shared. Information was gathered from these meetings for the construction of Rosa do Mar's narrative through "conversations"; some audio was recorded. There was an understanding that the biographical narrative creation of Rosa do Mar was made possible by a relational environment, permeated by affection, uniqueness, and vulnerability [23], and by sharing and collecting oral accounts, and visual and textual documents [19] which materialized it through the doubts, concerns, and theoretical systems that were mobilized from an understanding of the narrative that is built from life history [27].

Operationalizing the biographical narrative is possible through its recognition as a methodology framed by the phenomenological-interpretative paradigm of hermeneutic-relational thinking [17]. This methodology comprises a multiplicity of "techniques", "strategies", and "instruments" of information collection/sharing that allows for understanding the phenomenon-which is complex-under study. Analysis of the narrative takes into account place, temporality, and sociability [26]. The privilege of living awakens as a nodal component of the constitution of field and research texts, revealing the form of analysis [31]. The analysis process was based on the heuristic triad, hermeneutic interpretation, 
and profound implication of the researchers [17]. We began by bringing into dialogue the field notes (more immediate and less expressive records) collected during the encounters. Subsequently, from these notes, field texts were compiled. According to Clandinin and Connelly [17], field texts are more descriptive than reflexive and should be considered at maximum sensitivity to the experience in the research scenario with the participants. In this process, we unconsciously created metaphorical correspondences between two sets of narrated experiences [32]. After that, we were able to create biographical narratives as research texts and to start the analysis. We reached a dimensional system that seeks to account for different dimensions narrated, organizing them into a framework of dimensions and subdimensions that were valued in relation to the study's conceptual problematization [33]. The analytical model for this paper comprises three different emerging dimensions: seducing people, agencying places, and governing senses. As specificities of this research method, the different constituent elements of the narrative will be particularly understood in this three-dimensional analysis of the phenomenon [19]. As stated by Thomas Dotta and Lopes [32], the process of analysis resulted from a process of narrative thinking, imagining the phenomenon to be investigated as a three-dimensional living space and as a conceptual structure of data analysis. Narrating, therefore, is always an act of experience [33].

From these assumptions-and since the aim of this work is to problematize the meanings that are attributed to experiences lived by a primary-school teacher about her school experiences with the expressive arts education, understanding tensions that are established in the performance of her profession-it is possible to begin the debate about the life history narrated above. This is possible by taking into consideration the flowing aspects: her education as a primary-school teacher; her curricular and pedagogical work in the area of expressive arts education; and, finally, the artistic expressiveness of her body-in which Rosa do Mar remembers, is surprised about, and dreams of.

The articulation of the empirical work carried out with this theoretical debate now takes shape.

\section{Expressive Arts Education in Rosa do Mar's Teacher Education}

The initial teacher education that would allow Rosa do Mar to become a teacher in basic education came after a sociocultural and political rupture with the fascist regime [34] of a repressive and authoritarian environment [35] which characterized the Portuguese political scenario influencing social life:

My father was very, very oppressive; very dictatorial; [and] very against girls studying. I only continued studying because my primary teacher insisted a lot and my mother begged him; so, in the end, he let me go and study. (Rosa do Mar)

It was after the 1974 revolution in Portugal that Rosa do Mar joined the Primary Instruction School. During her initial teacher education, she was able to experience expressive arts education. In the curricular plan of her initial teacher education, decreed by Order no. 157/78 of 30 June 1978, she studied areas of "expression and communication", comprising the specific areas of "communication and visual expression", "musical expression", and "movement and drama":

I remember what we did in class, living the music, each in his own way; interpreting the music; doing like the seeds; blossoming with the music; pretending; [and] cutting each other's hair, the sounds of scissors. (Rosa do Mar)

With the revolution, the fascist regime, which was permeated by the values and ideologies of the so-called Estado Novo and which set technical and conservative objectives for the initial education of teachers in Primary School [34], fell apart, allowing the creation of a new social and political system. This new system brought the possibility of social and cultural manifestation-personal and collective-and allowed for the development of new understandings about the bodies that inhabit it [36]. According to Manarte [37], what could be considered a "body-object" was reinvented and it became possible to envisage the subject intrinsic to it. At the same time, other educational options were being structured, namely in the area of education through art [38]. Later, at the end of the 1970s, 
a proposal for a National Plan of Artistic Education emerged. This was a period of arising opportunities for artistic expression in school.

Social and political changes in the initial teacher education began to be a concern [34]. In the specific field of expressive arts education, Oliveira [39] considers that curricular changes have taken place mainly as a result of advances in artistic practices and research, where, however, criticism can still be made of the initial education of teachers that slowly accompanies such processes [40].

The contact with cultural and artistic production, recognizing the aesthetic elements present in the daily life of the student (future teacher) and the contact with artists-and their ways of thinking and creating-is, since the beginning of the new millennium, pedagogically framed in the initial teacher education [41] as one of the strategies to initiate the relationship of future teachers with artistic expression. In Freedman's [11] conception, this happens as result of the expansion and global influence of visual culture, a culture, according to the author, that influences personal identities and organized structures. The same author considers that [11], through lived experience with the growing reach, availability, and speed of visual forms created by artists (intentional) and all of us (in daily life), expressive arts education has been establishing new global significances. It is, therefore, important to continue the work of relating the future teacher to the pedagogical work of the curricular part of education and artistic expression through processes of critical reflection that are attentive to the aesthetic and artistic multiplicity [39]. An arts-based research developed by Carpenter II and Tavin [16], acknowledging art education as still fragile and struggling, provides arguments for the possible reconceptualization of art education advocating for students to critically investigate their own culture. They show - in this sense of visual culture intensity-this necessary education process based on people's lives. To the same authors, this is possible by providing an understanding of art education as a symbolic representation that also "embrace[s] different symbolic representations as meaningful content for the field" [16] (p. 16). In other words, this is possible by moving from a traditional paradigm of modes of media and methods to one that includes big ideas, postmodern principles, and key concepts for education, schools, and teachers.

It is from this relationship between the lived experiences of future teachers, influenced by the context of learning and contact with specific knowledge (the curriculum in Bruner's [14] conception) that education and artistic expression are made possible, enhancing the approach to artistic expressivity of the body:

In our time, when I taught, [ ... ] we came out with many ideas; they were professors who enlightened us, who gave us hope; we were loaded with ideas and wills, to do different things.

(Rosa do Mar)

It is between the continuous teacher education offered by higher education institutions and the artistic practice in her home studio that Rosa do Mar continues to invest her time with the aim of establishing herself as a capable teacher-of surprising and dreaming — where she recognizes others as involved participants.

Around the year 2009, Rosa do Mar returned to higher education for the development of continuing teacher education, focused in the area of expressive arts education. This was a period already influenced by the first World Conference on Artistic Education, which took place in 2006 in Lisbon (Portugal), where art, artistic expressions, and education were problematized as fundamental areas for the development and reinforcement of creative capacities and a cultural awareness of the 21st century, producing a roadmap for artistic education. In 2007, the first National Conference on Artistic Education was held in Porto, with Rosa do Mar participating and being much admired by her peers.

To the school level, national program were also promoted to encourage the arts, such as the Full Time School Programme, which includes Curricular Enrichment Activities (AEC), regulated by Order No. 12591/2006 of 16 June, and the Aesthetic and Artistic Education Programme in 2010.

Thus, in this climate of effervescence and social unrest, Rosa do Mar participated in training actions for continuous teacher education but became very critical of her experiences: 
Life [and] the world evolves; we evolve. We have to, throughout our lives as teachers, train [and] keep up with it. Now, what bothers me is how these programs are constituted. (Rosa do Mar)

I've participated in several [teacher education programs], and there are some that have left me completely, completely discouraged. [ ... The professor] came all happy with a little box with two or three art pieces ..., and when a person arrives there and tell her some things, she puts [it] aside. [ ... ] Honestly, I felt like showing her my boxes. (Rosa do Mar)

\section{Curricular and Pedagogical Work between Expressive Arts Education and the Artistic Expressiveness of Rosa do Mar}

According to Eça [25], the development of expressive arts education at school should focus on teachers, recognizing their acquired skills and training, avoiding them being characterized as "gear pieces". In this way and in an environment of sharing, it is possible to value the knowledge, techniques, and processes of artistic expression and to be a teacher [25]:

I feel that I have to educate my colleagues, but who wants to learn? And, at what times does education take place? In class-time, you can't. [Teachers] are on duty. In [their] extra time, does the teacher come to work in the evenings? And, do they want to come here? Extra service time? They don't want to. I do what I like because I like it. I do it like this. I do it, and I feel happy. I feel tired but happy. When I'm told, 'you like it.', I like it, but I also like collaboration. And, I have people who collaborate, but this can't be like that. The educational programs have to be done, and [teachers] have to show proof that they are done because artistic expressions are as important as reading, writing, and telling. (Rosa do Mar)

The multiplicity of circumstances surrounding the curricular work allows its problematization in two major dimensions: the knowledge and the specificity of that knowledge, and the coordination and organization underlying that knowledge-the curricular work of the curriculum (all living experiences in school). As the work of the primary-school teacher is characterized by single-teacher work [34], other challenges emerged. Rosa do Mar, as a primary-school teacher, was a librarian. Her personal motivation for the curricular work of expressive arts education which leads her to entice others began on a journey that would eventually extend to the entire Portuguese territory. From North to South, Rosa do Mar could learn and teach:

To each teacher who arrived, I made sure I was in the Jeep to received them [at] the train station: the delegate, the new teacher, and me. I would always go along. Therefore, I got to know the whole Odemira municipality, and it did me good because I also started to contact [and] to meet new people. (Rosa do Mar)

The following year, I was placed very far away. Thinking I was going to stay in Porto, I went to Mancelos, which is past Amarante. (Rosa do Mar)

From these travels, she had experiences [13] that would translate into knowledge in her professional practice. From the perspective that the management of pedagogical work is based on the paradigm of communication [42], where educating is meant to allow the other to know himself/herself and to know others who are involved with him/her and who are around him/her, in a learning environment, Rosa do Mar allowed herself to also be influenced.

Artistic expressions as language, when understood by the human being, make it possible for one to express their feelings through their emotions [43,44]. From conventional settings such as visual-plastic expression, musical expression, and dramatic expression, which are the most frequent opportunities for artistic experience in school [40], it is possible to attribute quality to the expressive act. A recent study [45] that aims to determine how art education influences students' preferences for the 20th 
century in primary schools found that it was (mainly) through visual-plastic expression that positive reactions emerge. According to Dewey [12], activities such as drawing, dancing, and singing are some of the organization-convened artistic languages that enable people to express themselves. Each of these languages-and so many others-has the potential to express emotions that are experienced [12]. In this line of thought, the body becomes a reference [46]. The importance given to the range of senses in a body, whether it is the eye that allows drawing, the touch that allows dancing, or the ear that allows singing, according to Dewey [12], should not be considered the most important agent. According to the same author, it is important to experience artistic expression as a complex, intense, and vital experience that is not limited to the exclusivity of the senses in the body. From this idea of a "whole that is fulfilled" [12,13], we are aware that all experiences have a principle and follow its own course until its "consummation", revealing artistic expression as an anthropological value:

The preparation [for curricular work] is made possible by our experiences. I remember all the plays that I have been in and all the drawings that I have made, and what I think is that a teacher is the better teacher, the more artistic skills she has. (Rosa do Mar)

Artistic expression as communication reaches different potentialities and possibilities through the relation of the body with different artistic means, such as watercolor ink in visual-plastic language, the flute in musical language, or the accessories in dramatic language. According to Eisner [1], the visual, musical, and dramatic qualities of the different possibilities of certain means of expression are distinctive. Expression through watercolor ink differs from expression through oil ink, and expression through a flute is different from expression made possible through a bass violin. According to Eisner [1], each artistic means-hereby identified through instruments and materials—imposes its own distinctive demands:

Because the arts, as long as they know, are much more motivating for kids, you grab them around. It's a good way, and then, you get to do a bit of what you want with them. When I have a class, I negotiate: I negotiate with them through arts. We have to work in every art front, on what I want and on what they want. (Rosa do Mar)

Artistic expressions as curricular knowledge in a vision of the necessary epistemological and methodological rupture of expressive arts education is the idea defended by Atkinson [47] and Baldacchino [48]. The authors consider that art in education and artistic expressions in school should be unlearned. For Baldacchino [48], unlearning emerges from the idea of studio-based learning - a reference to the artistic work done and the ways to learn through relations in artist studios (master/students/materials/working processes, etc.) which are institutionalized. For Atkinson [47], this discussion is a more political one-with reference to the ways one sees art education and artistic expressions from the "school art style". Being aware that how we look at areas of artistic expression at school today is conditioned by beliefs inherited from the past [47] and since people are often induced to think within preestablished constructions [48], the democratized knowledge with which they grow (societies) becomes demarcated [47]. Adopting the perspective that school's artistic expression curriculum design should promote induction rather than deductibility [1], the ideal argument for the development of critical and creative citizens of intervening power through artistic expressions, as school knowledge, can be enshrined.

When you realize it, you're working on wishes. [ ... ] Everyone gets involved. [ ... ] It is to this extent, I think, that the expressive arts education should be in basic education. They must be and they are, but they are very much in tune, and with this history of curricular enrichment activities, the primary teacher has sent those artistic activities to out of the educational program. The music, with the music teacher; the visual-plastic, with the visual-plastic teacher; the dramatic, with the dramatic teacher; and that little that was done in class [are] no longer done. (Rosa do Mar) 
Against this global idea, Eça [25] reinforces the importance of the arts, in their specificities, being worked on and mobilized in a specific and individual way, thus avoiding that its integration in a unique and holistic approach weakens the artistic expressiveness of the body. On the other hand, being centered on the production of meaning in the first years of education -with all it involves, whether by the education of teachers working at this level or by the conditions that working environments offer-it is important to reflect on how primary-school teachers organize their knowledge. For example, knowledge fragmentation in basic education or "disciplinary division" [42] leads to an educative crisis. In this line of thought, we assume that, in a realistic way, this is a difficult goal to achieve. Focusing only on that idea creates controversies in expressive arts education [49], influencing school experiences.

Recognition of the curricular work of expressive arts education as being inherent or not to the work developed by the primary school teacher has been the subject of problematization [49]. Rosa do Mar problematizes it from a multidisciplinary conception, where collaboration is necessary to bring together people with different knowledge. The attribution of certain types of knowledge to certain teachers without the participation of primary-school teacher is, in her opinion, limiting the expressive capacity that can be developed in schools with children. In the wake of this thought, Cosme and Trindade [42] refer to the need to recognize, through the paradigm of learning, in the pedagogical work that children possess knowledge and intellectual and cultural resources of their own. Rosa do Mar states that acknowledging such specificities in the curriculum in a corset way limits the opportunities for children's personal and unique expression. Thus, in this atmosphere of curricular work, Rosa do Mar allows us to weave concerns and some considerations about the personal expression and artistic expressivity of the body [46].

Problematization of the subject has been transformed by direct influences from educational boards and management groups-both by guidance that creates stability in professional performance and by guidelines that destabilize the educational practice of teachers. Historical marks are blended into contemporary life stories.

\section{Rosa do Mar's Personal Expression and Artistic Expressivity}

Problematization of human being's expressive act and its expressiveness-of emotions-allows for different ways of understanding an emotional body to be able to manifest itself [46]. "Emotions" are conceptually foreseen as a cognitive act, "a motivational struggle caused by cognition and an awakening caused by both" [43] (p. 44). It is possible to differentiate emotion from the feeling of this emotion and from the knowledge that we have about the feeling of this emotion [44]. From the understanding that the human being begins to express from birth [2], the distinction between expressive act and expressivity must then be situated [50]. Taking into consideration the understanding that the human being expresses as a result of the relationship between internal and external tensions [42,51], with personal and intimate objectives, or with communicative objectives perceived by others [1,12], we state artistic expressivity as an expression with quality [12]:

The school management never, never gave much value to my work, although I thought the work would come about, but they never gave me feedback. [ ... ] However, the direction changed. [ ... ] That was the green light, a very great force for my work. (Rosa do Mar)

Expression as a human act of communicating feeling also perceptible by others, associated with the "artistic", and as a characteristic of art that attributes quality to the act [2] is problematized in this work from the design of artistic expression, that is, an act of qualified manifestation [12]. According to Dewey [12], artistic expression is a qualified organization of personal and social means of artistic expression. Eisner [1] agrees with this understanding, arguing that artistic expression is the attribution of (special) qualities that form and inform representations:

In classrooms, some do illustrations, others tell stories, others perform role-plays, and often these works are presented to parents. Occasionally, we bring the community to the school. 
All it takes is one song. All it takes is one reading, one poem. The parents come and thank you.

(Rosa do Mar)

Expressivity is the attribution of meanings that is translated as a result of expression [50]. In this work, artistic expression is recognized as an area of human life privileged in the body expressivity. Rosa do Mar's lived experiences in school are a way for the expressive arts education to be alive. Rosa do Mar appropriated, between all the conditions that are preconized, expressive arts education through her artistic expressiveness.

Rosa do Mar, already in her full capacity as a librarian teacher without the assignment of classes and working in the School of Stories, a primary school, and although being close to her retirement, still organizes and promotes experiences:

[The library pass for entry] was sold out. There were full pillows. There were missing chairs.

There were about 60 children. [ ... ] It's something, and to be the engine ... , from here come the branches. (Rosa do Mar)

From musical expression, through theatre, dance, and visual and plastic arts, various artistic languages-with their own grammars-come together in an educational project for the first years of basic education. From personal expression to artistic expressiveness of the body, a growing complexity of senses and meanings is evident, attributed according to lived experiences (see Figure 1):

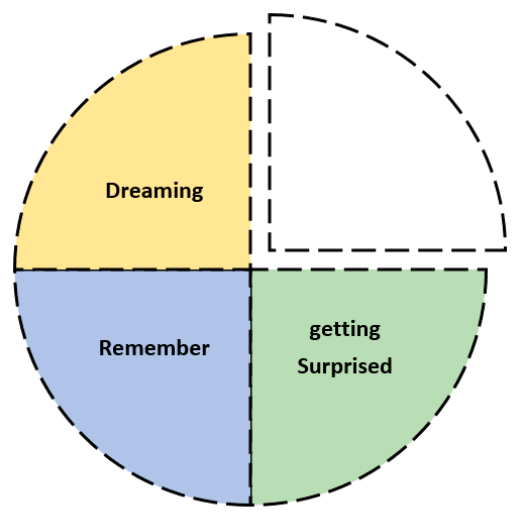

Figure 1. Schematic, produced by the authors, of a three-dimensional analysis of the life history of Rosa do Mar.

[General primary school teachers] don't work so systematically this area, but this gets caught up. It's almost like starting to eat it. A person does not even have an appetite but it gets there, and as some teachers talk about what they do, they catch each other and then even say: "look, you know, I worked on what you told me, and look, it worked. It gave a narrative text. They worked on poetry. They made it dramatic." and "They make the noises; they work making noises: 'What do you think this character's expression is like?'” And, they do the theatrics in their own classrooms. It's fun to come into the classroom [when] they're doing a dramatization of a text they've been reading. Now, that's expression work. (Rosa do Mar)

It is, then, in this perspective that the body with emotions is recognized and understands, framed in a social, cultural, and political context that influences and is influenced. By reviewing and exploring the main ideas and concepts so far presented, it is possible to weave a few considerations on Rosa do Mar's life history, taking into account the different dimensions of analysis, with Rosa do Mar as a seducer of people, an agent of space, and a governor of the senses, through memory, surprises, and dreams. Such considerations are in relation to some of the possible dimensions to be analyzed with the intention to reconceptualize expressive arts education in schools. Although the biographical narrative presented above comprises other dimensions of Rosa do Mar's life history, this paper will only focus on the three considered as more relevant for this work. 


\section{Discussion}

\subsection{Seducing People}

Even on the digital social network, I work with colleagues; I publish some things from school, and people give a lot of feedbacks. There was once ... a colleague; she presented [on the social network] a work she did with the kids from a tree on her head, "The man who had a tree on his head", and I said, "look, I have this book in the library." and she says, "I didn't know! So, I'm going to the library!" And, there you go; that kind of situation is very rewarding. (Rosa do Mar)

Many people participate in Rosa do Mar's life story. We can understand that their participation is at the level of their contributions to the experience of Rosa do Mar, as it is the case of the memory of the music teacher from the initial education course quoted above as well as of the people who end up being influenced by the contributions of Rosa do Mar, namely the primary-school teachers with whom she regularly collaborates and is surprised by. The work of seduction, due to an admissible desire [36] which is the motive and motivator for Rosa do Mar's action and participation in school life, is also enhanced by the seduction of external stimuli-as is the case of the courses and events in which she participates.

At the national level, there have been social, cultural, and political initiatives that directly and indirectly influenced Rosa do Mar, specifically in teacher education, beyond those mentioned above. The activities of the Calouste Gulbenkian Foundation (the Calouste Gulbenkian Foundation, created in 1956 in Lisbon, has as their main purpose the improvement of the quality of life through art, charity, science, and education) have been challenging practices and theories in teacher education, enhancing programs where the role of the arts in education is valued and distinguished [5]. The different people involved in these initiatives are recognized by Rosa do Mar as important agents of educational transformation. She was also seduced by them to do more and better-allowing herself to dream about them and for them. This is linked to the idea that the conscience of art education is made by people and through people. According to Dewey [12,13], we live in a world in constant exchange of ideas, lived by different substances and forms [52]. This creation of life (and of art) happens in between [11]. Rosa do Mar assumes the responsibility of continually seducing people. On the micro and private levels, this attitude was strengthened by the "encounters" between the researchers and Rosa do Mar-it flourished, allowing, for example, this paper as a materialization of experiences lived between life and art.

\subsection{Agencying Places}

Here [at the School of Stories], things are always happening. The schedule work: this subject came up because I thought it was a shame that this space was closed during break time; it did not make sense for us to have a cozy space here and the kids could not use it, and I thought of a strategy. I started by inviting classes. On Monday morning is the first A class [and] in the afternoon is the second B class, doing it in order until all the classes come back. Then, I started to realize that it would not happen because there were kids that did not come and there were empty spaces, empty spaces. They always came and went the same way. So, I said, "That's it; it doesn't work. I've made a habit of some; those who like to come will come, so now I'll make it general. Only those who want to come, come, and it's not by classes." They start to come, but we have to schedule how many kids can come because we want a center to recreate and have fun in that free hour but you have to have rules; you have to have the spaces organized; and, inside the spaces, you have to have something for them to do. And then, we would stand there at the door, "You want to go where? There. You want to go where? There." (Rosa do Mar) 
The School of Stories, as a privileged space for encounters between the researchers and Rosa do Mar, is also one of Rosa do Mar's most loved places. It is located in one of the eighteen municipalities of the city of Porto, in the north of Portugal. It is surround by local commerce, with specialized services. From the School of Stories-which gives its name to the school—to the entrance gate-which is also an exit gate-Rosa do Mar finds possibilities for action-which involve its necessary management. Based on Ribeiro's [53] understanding of the place as a context that not only is topologically located but also goes beyond its physical characteristics, it makes sense to establish a parallelism with Rosa do Mar experiences.

"Even when she is at all prevented from realizing her creative potential on the ground floor of reality, there is always [ ... ] some space left to install her 'art studio' in the attic of fantasy." [53] (p. 79). The author refers to children as spontaneously creative beings who, even in adverse physical contexts, manage to create [53]. Rosa do Mar is a grown woman who dreams; who fantasizes; who also, sometimes, imagines herself as a child in her teacher role at the School of Stories. This notion of Rosa do Mar as a teacher and creator, who dreams and imagines, allows for the introduction of new concerns about her profession. Thus, beyond what is physically (located) conditioned and limited in the different places inhabited by Rosa do Mar (mainly the School of Stories with all the straight walls and heavy doors) is the idea that it is possible to reinvent these places as reconceptualized spaces. From her initial education as a teacher, it is possible to problematize how biographies could influence formative processes during the teaching profession. In the wake of this thinking, research recently developed on life stories as learning strategies in teacher education courses accounting for the living space and time of as a prime principle [54-56] provides some answers for this necessity. Concerning curricular and pedagogical work, Rosa do Mar's biographical narrative shows a greater physical concentration in the School of Stories, with the existence of spaces such as classrooms or other places that facilitate and enhance the development of her professional performance. Her personal expression and artistic expressivity, then, enables her to exist in the spaces of the school as well as in her home (particularly, in her art studio). These are the two main places of reference for Rosa do Mar.

\subsection{Governing Senses}

To value [and] to say that the artistic activities value students' learning and stimulates their expressions, that is what is needed. These evidences have to be portrayed in the reports of the [primary-school teachers] and in their evaluations when I ask them quarterly to evaluate the School of Stories. When I see in an evaluation minute, they evaluate if "activities have gone according to plan", I freak out. Is that something? In addition, what was the stipulation? The stipulated was from then on, and what was done? What was the involvement of the kids? What did the kids feel? I am amazed when they send me this. What is the point of this for me to defend the School of Stories and the work we have done here? This is of no use at all. (Rosa do Mar)

The recognition and appreciation of the experiences that have become significant throughout Rosa do Mar's life history allow for their interpretation in two extensions: orientation of the senses experienced by others which are influenced by Rosa do Mar and by how they manage their own senses in relation to their particular experiences-which may also be in relation to others. Initially, still thinking of herself as a girl, Rosa do Mar perceives herself as someone apparently unsuited to the world that would receive her and her profession. With few taking her seriously, she needed to reaffirm herself in relation to the perception that others produced about her. Rosa do Mar rejects the possibility of transforming herself or of annulling herself. Rather, Rosa do Mar reaffirms her position and her way of being in school and in the world.

The enrollment in the teacher education course in 1974, which provided her with the opportunity to work as a teacher in basic education, was a surprise. She met people who became her friends to this day. She was able to travel around the country, giving meaning to the landscapes that became the setting for her experiences. She understood new schemes of knowledge production, constituting for a 
new grammatical system where artistic expressivity was manifested in her life with special emphasis. Rosa do Mar learns and teaches. In 1979, already exercising her profession, she allowed herself to consider the absence of definitions that translated her experiences; rather, she allowed herself to imagine and dream about them. According to Nóvoa [34], there are also institutional and political epistemological pressures that condition action (in a post-revolutionary scenario), but despite these constraints to the work in education, it is still possible to be a teacher [3]. We become more aware of this when researching the specific area of artistic expression. We share the idea of Bezelga [41] and Oliveira [39], based on Eisner's [1] principles, that a primary school teacher in relation to expressive arts education is built on a critical awareness of the limitations of knowledge. Rosa do Mar became critical of the different aspects of her profession, with particular involvement in the curricular and pedagogical work that was developed and with the education that prepares teachers. She recalls having followed reports such as those of [57] that still inform on the insufficient education that primary-school teachers receive for their professional exercise in education of artistic expression in Portugal. The same is still evident today $[7,22,49,55]$.

\section{Conclusions}

We were "blessed" with the life story of Rosa do Mar through her biographical narrative. Recalling the aim of this paper, which was to problematize the meanings that are attributed to the life history of a teacher of the first years of basic education concerning her experiences with expressive arts education and understanding the tensions that are established in the performance of her profession through her life history, the main points of discussion and their results are now organized.

In relation to expressive arts education as experienced by Rosa do Mar, we understand the great influence of the 1974 revolution as a social and culturally significant period in her life history, having impacted her initial teacher education course. In consideration of the curricular and pedagogical work between expressive arts education and the artistic expressivity of Rosa do Mar, the problematization between the responsibility of such a curricular area is evident, and there is room for the problematization between the opportunities and constraints associated with the existence of specialist art teachers in the first years of basic education. Rosa do Mar's personal expression and artistic expressivity allows the affirmation of a body that reinvents itself, mixed with the different artistic languages in order to constitute discourses that express senses attributed by it throughout the life history.

In short, Rosa do Mar's biographical narrative reveals three constituent dimensions: people, unveiling how she seduces people and is seduced by people; places, in which she participates and manages through her agency; and the senses she attributes by managing knowledge and events. Such dimensions of analysis are not explored exhaustively in the narrative, but they enhance the production of knowledge in this area [33]. There is an urgent need to promote research in education and in art education through biographical and narrative methods, which are complex pedagogical processes, promoting a relationship close to scientific knowledge to a pedagogical-didactic formation in a multidisciplinary education [17], that problematize life stories as knowledge-producing systems [18,33]. The convergence of knowledge produced from artistic expressivity experiences in school, framed by education and everyday life experiences, makes our idea of "how to do art education" possible. This refers to knowledge produced in the field of arts education made from biographical narrative approaches $[11,45,49]$.

As an effect of the research, the detailed exposition intends for these stories to be an opportunity for the expression of the power of being a teacher capable of appropriating the educational government recommendation, consecrating it in their school practice. This practice enhances the subject's self-knowledge and emancipation [12] by recognizing Rosa do Mar's experiences with the artistic expressiveness of her body. Therefore, it can constitute a conscious agent, acting according to it [52]. We consider that this is made possible by the narrative power. We intended to develop this research from the perspective of valuing what is done, in spite of what should be done. It is based on the assumption, as it has been problematized, that, by saying, telling, and reflecting on stories of experiences of what 
is done, what has been done, and what one intends to do, it is possible to achieve more significant appropriations than those met by the "what should be done" discourse. This is our argument: Value living experiences as a process of self-education and, mainly, as a key element in learning "how to do art education" [16].

Narrative research is used as a strategy to enhance teacher's knowledge since two principles are assumed to be achieved with this research. The first refers to the possibility that such an attitude implies: to create and recreate spaces of personal and social significance to which the teacher is a part [24]. The second principle is characterized by the actions that such a commitment generates: with the possibility of teachers speaking and being heard, the whole school gains meaning [58]. On professional development, it is taken into consideration that this methodological approach enables the development of new perspectives on the social construction of the education system and teaching process [20]. The teacher involved in the reflection of their pedagogical practice enhances their subsequent experiences in exercising their profession [22]. These considerations, which have been highlighted, when associated with narrative methodology, allows for these efforts to be maximized. In recent years, work developed in the Ibero-American setting has shown that teacher education processes based on narrative methodologies, upon which the trainee's experience is reflected [59], preparing them in these modes for their future profession, result (1) in taking on students as active participants in their education [34], influencing learning processes, curricula, and educational policies [32], and (2) in assuming the work of emotions (tensions, anxieties, weaknesses, and potentialities) with which one is confronted in daily practice [24,54], producing processes of personal significance and social commitment, moving towards the educational reform that is being devised, that is, a presence with conscience $[37,55,56]$.

It is in these ideas that the force of our argument of the recognition of living experiences resides as the way for necessary expressive arts education reconceptualization in the first years of basic education.

Author Contributions: Conceptualization, A.F.; software, A.F., P.N., and F.P.; validation, A.F., F.P., and P.N.; formal analysis, A.F., F.P., and P.N.; data curation, A.F.; investigation, A.F., F.P., and P.N.; resources, A.F.; visualization, A.F., F.P., and P.N.; project administration, A.F.; funding acquisition, A.F., F.P., and P.N.; methodology, A.F., F.P., and P.N.; supervision, F.P. and P.N.; writing—original draft, A.F.; writing-review and editing, F.P. and P.N. All authors have read and agreed to the published version of the manuscript.

Funding: This research was supported by the Foundation for Science and Technology (FCT), IP (an organ of the Ministry of Education and Science of the Portuguese Republic), and by the European Social Fund (ESF), through the Human Capital Operational Programme (POCH) of Portugal 2020 (fellowship with ref. PD/BD/128279/2017, in the scope of the FCT PhD Programme in Education Sciences of the University of Porto); it was also supported by national funds through the Foundation for Science and Technology, I.P, under the scope of the Strategic Programme of Centre for Research and Intervention in Education of University of Porto, Portugal (ref. UID/CED/00167/2013).

Acknowledgments: We would like to thank all the children and all the teachers of the first years of basic education participating in the research project "(In) visibilities of artistic expressivity in the first years of basic education: experiences of teachers and students" from schools in Porto, Portugal, and in Rio de Janeiro, Brazil. In particular, we would like to address special thanks to primary-school teacher Rosa do Mar, who made this paper possible. Writing a paper with all this complexity is never easy. We were lucky to have Thiago Freires, a friend, as a reviewer-for his encouragement, making sure we would cross the road safely. We are very, very grateful.

Conflicts of Interest: The authors declare no conflict of interest.

\section{References}

1. Eisner, E. Reimagining Schools; Routledge: New York, NY, USA, 2005.

2. Read, H. Education through Art; Plantheon: New York, NY, USA, 1943.

3. Pereira, F. Infância, Educação Escolar e Profissionalidade Docente: Um Mapeamento Social Dos Discursos em Formação Inicial de Professores; Calouste Gulbenkian Foundation: Lisbon, Portugal, 2010.

4. CNE. Importância da Educação Artística no Sistema de Educação e Formação; Recomendaçãon ${ }^{\circ} 1 / 2013$; Ministério de Educação de Portugal: Lisbon, Portugal, 2013.

5. Fróis, J. Diálogos Com a Arte: Experiência Estética e Criação de Sentido; Lisboa University Press: Lisbon, Portugal, 2013. 
6. EACEA. Educação Artística e Cultural Nas Escolas da Europa; Ministério da Educação de Portugal: Lisbon, Portugal, 2009.

7. Giráldez, A.; Palacios, A. Educación Artística en Iberoamérica: Educación Primaria; Organización de Estados Iberoamericanos: Madrid, Spain, 2014.

8. Martins, C. Creative Primary School Partnership with Visual Artists; Porto University Press: Porto, Portugal, 2018.

9. Freedman, K. Artmaking/Troublemaking: Creativity, policy, and leadership in art education. Stud. Art Educ. 2007, 48, 204-217. [CrossRef]

10. Efland, A. Art education as imaginative cognition. In Handbook of Research and Policy in Art Education; Eisner, E., Day, M., Eds.; Taylor \& Francis: London, UK, 2008; pp. 751-774.

11. Vermeersch, L.; Elias, W. The End of the 'To-Do-List'. Towards a Balanced Arts Education. In Arts Education beyond Art: Teaching Art in Times of Change; Heusden, B., Gielen, P., Eds.; Valiz: Amsterdam, The Netherlands, 2015; pp. 113-130.

12. Dewey, J. Art as Experience; Perigee: New York, NY, USA, 2005.

13. Dewey, J. Experience and Education; Kappa Delta Pi: New York, NY, USA, 2015.

14. Bruner, J. Para Uma Teoria da Educação; Relógio D'Água: Lisbon, Portugal, 1999.

15. Freedman, K. How do we understand art? Aesthetics and the problem of meaning in the curriculum. In On Knowing: Art and Visual Culture; Duncum, P., Bracey, T., Eds.; Canterbury University Press: Canterbury, New Zealand, 2001; pp. 34-46.

16. Carpenter, S., II; Tavin, K. Drawing (Past, Present, and Future) Together: A (Graphic) Look at the Reconceptualization of Art Education. Stud. Art Educ. 2010, 51, 327-352. [CrossRef]

17. Clandinin, D.J.; Connelly, M. Pesquisa Narrativa: Experiência e História em Pesquisa Narrativa; Uberlândia University Press: Uberlândoa, Brazil, 2011.

18. Bolívar, A.; Segovia, D. La Investigación (Auto)Biográfica en Educación; Octaedro: Barcelona, Spain, 2019.

19. Bolívar, A.; Domingo, J.; Fernandez, M. La Investigación Biográfico-Narrativa en Educación: Enfoque y Metodologia; La Muralla: Madrid, Spain, 2001.

20. Goodson, I. The rise of the live narrative. In The Routledge International Handbook on Narrative and Life History; Goodson, I., Ed.; Routledge: New York, NY, USA, 2018; pp. 11-22.

21. Clandinin, D.J. Handbook of Narrative Inquiry: Mapping a Methodology; SAGE Publications: Thousand Oaks, CA, USA, 2007.

22. Goodson, I. Histories of the life of the teacher. In Historias de Vida del Professorado; Goodson, I., Ed.; Ocaedro: Barcelona, Spain, 2004; pp. 27-46.

23. Clandinin, D.J.; Caine, V.; Lessard, S. The Relational Ethics of Narrative Inquiry; Routledge: New York, NY, USA, 2018.

24. de Souza, E.C. Territórios das escritas do eu: Pensar na profissão-narrar a vida. Educação 2011, 34, $213-220$. Available online: https://revistaseletronicas.pucrs.br/ojs/index.php/faced/article/view/8707 (accessed on 17 September 2020).

25. Eça, T. Desenhar um Currículo de Artes entre as Especificidades Regionais e as Orientações 'Translocais'. Rev. Port. Educ. Artíst. 2011, 1, 45-51. [CrossRef]

26. Clandinin, J.; Pushor, D.; Orr, A. Navigating Sites for Narrative Inquiry. J. Teach. Educ. 2007, 58, 21-35. [CrossRef]

27. Amado, J.; Ferreira, S. Estudos (auto)biográficos-Histórias de Vida [(Self-)Biographical Studies—Life Histories]. In Manual de Investigação Qualitativa em Educação, 3rd ed.; Amado, J., Ed.; Coimbra University Press: Coimbra, Portugal, 2017; Volume 1, pp. 171-187.

28. Josselson, R. The ethical attitude in narrative research. In Handbook of Narrative Inquiry: Mapping a Methodology; Clandinin, D.J., Ed.; Sage: Thousand Oaks, CA, USA, 2007; pp. 537-566.

29. Pereira, F. Educação Pública, Formação de Professores e Epistemologia(s) do Trabalho Docente; Porto University Press: Porto, Portugal, 2016.

30. Levinas, E. Totalidade e Infinito; Edições 70: Lisbon, Portugal, 2018.

31. Polkinghorne, D. Validity Issues in Narrative Research. Qual. Inq. 2007, 13, 471-486. [CrossRef]

32. Dotta, L.T.; Lopes, A. Investigação narrativa, formação inicial de professores e autonomia dos estudantes: Uma revisão de literatura. Educ. Futuro Rev. Investig. Apl. Exp. Educ. 2013, 29, 129-155. Available online: https://dialnet.unirioja.es/servlet/articulo?codigo=4456848 (accessed on 17 September 2020).

33. Freires, T.; Pereira, F. Secondary specialist arts education: Perceptions of youths in Northern Portugal. Educ. Pesqui. 2018, 44, 1-16. [CrossRef] 
34. Nóvoa, A. Vidas de Professores; Porto Editora: Porto, Portugal, 1992.

35. Stoer, S. A reforma de Veiga Simão no ensino: Projecto de desenvolvimento social ou «disfarce humanista»? Anál. Soc. 1983, XIX, 793-822. Available online: http://analisesocial.ics.ul.pt/?page_id=12 (accessed on 17 September 2020).

36. Bauman, Z. Liquid Love: On the Fragility of Human Bonds; Relógio D'Água: Lisbon, Portugal, 2006.

37. Manarte, J.; Lopes, A.; Pereira, F. Contributions to the empirical study of immediacy in the pedagogical relationship through self-narratives. J. Pedagog. 2014, 5, 209-225. [CrossRef]

38. Santos, A. Mediações Arteducacionais; Calouste Gulbenkian Foundation: Lisbon, Portugal, 2008.

39. Oliveira, M. (Re)pensar a educação artística na formação inicial dos futuros professores. Rev. Port. Educ. Artíst. 2017, 7, 19-32. [CrossRef]

40. Freitas, A.; Mouras, A.; Pereira, F. Orientação do movimento pela educação das expressões: Perspetivas de professores em Portugal. Movimento 2017, 23, 1435-1448. [CrossRef]

41. Bezelga, I. Play, enjoy, experiment! The presence of the arts in the training of teachers and educators of children of the University of Évora. Poiésis 2018, 12, 167-184. [CrossRef]

42. Cosme, A.; Trindade, R. Organização e Gestão do Trabalho Pedagógico: Perspetivas, Questões, Desafios e Respostas; Livpsic: Porto, Portugal, 2013.

43. Arnheim, R. Consideraciones Sobre la Educación Artística; Paidós: Barcelona, Spain, 1993.

44. Kardum, G.; Kuscevic, D.; Brajcic, M. The impacts of different sorts of art education on pupils' preference for 20th-Century art movements. Educ. Sci. 2020, 10, 15. [CrossRef]

45. Ribeiro, A. O Corpo Que Somos: Aparência, Sensualidade, Comunicação; Casa das Letras: Lisbon, Portugal, 2005.

46. Atkinson, D. Art, Disobedience, and Ethics. In The Adventure of Pedagogy; Palgrave Macmillan: Cham, Switzerland, 2018.

47. Baldacchino, J. Art as Unlearning: Towards a Mannerist Pedagogy; Routledge: New York, NY, USA, 2019.

48. Freitas, A.; Mouraz, A.; Pereira, F. Controversies of Expressive Arts Education in Portugal: Insights from Policies and Practices. Knowl. Cult. 2020, 8, 77-93. [CrossRef]

49. Damásio, A. O Sentimento de si: Corpo, Emoção e Consciência; Temas e Debates: Lisbon, Portugal, 2013.

50. Robinson, J. Expression and Expressiveness in Art. J. Aesthet. 2007, 4, 19-41. Available online: http://debatesinaesthetics.org/postgraduate-journal-of-aesthetics-vol-4-no-2-august-2007/ (accessed on 17 September 2020).

51. Best, D. A Racionalidade do Sentimento: O Papel Das Artes na Educação; Edições Asa: Lisbon, Portugal, 1996.

52. Eisner, E. The Arts and the Creation of Mind; Yale University Press: New Haven, CT, USA, 2002.

53. Ribeiro, A. A Escola Pode Esperar; ASA Editores: Porto, Portugal, 2002.

54. Caetano, A.; Freire, I.; Sobral, C. Emoções e ética na formação de formadores. A complexidade em ação. Rev. Contexto Educ. 2018, 33, 119-138. [CrossRef]

55. Moldonado, B.; Prados, E.; Garcia, M. Reescribir el cuerpo educado. De la voz silenciada y la emoción contenida al cuerpo educando. Int. J. Dev. Educ. Psychol. 2017, 3, 377-386. [CrossRef]

56. Prados, E. Los lenguajes del cuerpo. Escenarios para reinterpretar la institución educativa. Rev. Infanc. Educ. Aprendiz. 2020, 6, 37-56. [CrossRef]

57. Xavier, J.B. Relatório do Grupo de Trabalho-Ministério da Educação Ministério da Cultura, Despacho Conjunto N. ${ }^{\circ}$ 1062/2003, DR-II Série de 27 de novembro; Ministério da Educação de Portugal: Lisbon, Portugal, 2004.

58. Pereira, F. Teacher education, teachers' work, and justice in education: Third space and mediation epistemology. Aust. J. Teach. Educ. 2019, 44,77-92. [CrossRef]

59. Elbaz-Luwisch, F. Teachers' Voices: Storytelling and Possibility; Age Publishing: Greenwich, CT, USA, 2005.

Publisher's Note: MDPI stays neutral with regard to jurisdictional claims in published maps and institutional affiliations. 